Spatial Theorizing in Comparative and International Education Research

Author(s): Marianne A. Larsen and Jason Beech

Source: Comparative Education Review, (-Not available-), p. 000

Published by: The University of Chicago Press on behalf of the Comparative and International

Education Society

Stable URL: http://www.jstor.org/stable/10.1086/675499

Accessed: 26/03/2014 11:57

Your use of the JSTOR archive indicates your acceptance of the Terms \& Conditions of Use, available at http://www.jstor.org/page/info/about/policies/terms.jsp

JSTOR is a not-for-profit service that helps scholars, researchers, and students discover, use, and build upon a wide range of content in a trusted digital archive. We use information technology and tools to increase productivity and facilitate new forms of scholarship. For more information about JSTOR, please contact support@jstor.org. 


\title{
Spatial Theorizing in Comparative and International Education Research
}

\author{
MARIANNE A. LARSEN AND JASON BEECH
}

\begin{abstract}
The authors argue for a critical spatial perspective in comparative and international education. We briefly summarize how time and space have been conceptualized within our field. We then review mainstream social science literature that reflects a metanarrative, which we critique for contributing to false dichotomies between space and place and oversimplified views of the relationship between the global and the local. We present some of the key ideas associated with the "spatial turn," including a relational understanding and productive capacity of space. In the final part of this article, we analyze the significance of new spatial theorizing for comparative and international education by reviewing examples of both comparative and educational researchers who are engaging with critical spatial theorizing. We argue that a possible way to confront binary thinking about space and place is by shifting attention to the relational conceptions of space, through analyses of networks, connections, and flows.
\end{abstract}

There are many reasons for the argument that we live in spatial times and that spatial thinking now matters (e.g., Massey 1993, 2005; Soja 1996, 2009; Warf and Arias 2009). Global transformations have provided us with opportunities to consider wider and more complex concepts of space and spatiality in our research. These include the changing nature and effects of the mass media and new information technologies, the predominance of free-market relations, migration within and across national borders, and increasing evidence-blatantly so-of cross-national environmental threats, including natural disasters. While such processes of globalization have provoked many researchers in the social sciences to rethink how they research and understand the social world, the field of comparative and international education has been slower to engage with spatial theories. We suggest that there is much to gain from foregrounding spatial thinking in comparative and international education research and offer our thoughts in this article on how and what that might look like.

Much research in comparative and international education is based on territorial and geopolitical definitions of space, mainly centered on the nation-state as a unit of analysis, which derive into binary distinctions between "the global" and "the local," despite the efforts of authors to attend to local

Received September 19, 2012; revised November 9, 2013; accepted January 8, 2014; electronically published February 7, 2014

Comparative Education Review, vol. 58, no. 2.

(C) 2014 by the Comparative and International Education Society. All rights reserved. $0010-4086 / 2014 / 5802-0005 \$ 10.00$ 
specificities (e.g., Baker and LeTendre 2005; Beech 2011; Arnove and Torres 2012). ${ }^{1}$ To overcome these limitations, we suggest that the field should engage more thoroughly in theorizing about the concepts of space and place and, in particular, understand space not only as an object in its concrete form but also as sets of relations between individuals and groups. In addition, we argue that the productive aspects of space should be given more attention in research in comparative and international education. In other words, we argue for the privileging of space and, in particular, spatial theorizing as a primary point of focus and framework for the comparative study of education.

In order to unfold this argument, we have divided the article into five sections. We begin with an overview of how time and space have been conceptualized within much comparative and international education research. In the second section, we review some of the mainstream literature in the social sciences, showing how the binary distinction between space and place has been constructed through a major metanarrative that takes for granted certain spatial changes from premodern to modern and globalized times. A critique and deconstruction of this metanarrative are offered by suggesting that the conceptualization of place as the local, the real, and the stable, and of space as the global, more abstract, and futuristic has contributed to false dichotomies between space and place and oversimplified binary views of the relation between the global and the local. In the third section, we note the reassertion of space in the social sciences and humanities, especially since the 1990s, in a process that has been labeled "the spatial turn." We then present some of the key ideas associated with the spatial turn, including a relational understanding of space and the productive capacity of space. This section works as a justification for our main argument that comparative and international education needs to engage more deeply in theorizing about space.

The final part of this article shifts to an analysis of the significance of new spatial theorizing for comparative and international education. We review and comment on two examples of research in our field that we have found promising, and three areas of study taken up by educational researchers engaging with critical spatial theorizing. We argue that a possible way to confront binary thinking about space and place is by shifting our attention to the relational conceptions of space, through the analysis of networks, connections, and flows. In particular, we suggest that some inspiration to move forward can be found in social network analysis. We provide some specific examples of what comparative and international education research might look like reimagined through the lens of new spatial thinking. Our argument, again, is that spatiality, the relations and productive capacity of

\footnotetext{
${ }^{1}$ The titles of Arnove and Torre's edited volume Comparative Education: The Dialectic of the Global and the Local and Baker and LeTendre's book National Differences: Global Similarities illustrate this binary thinking in suggesting that the global and the local/national are separate entities.
} 
space, can provide a relevant tool for the analysis of the comparative and international dimensions of educational research.

\section{Time and Space in Comparative and International Education: Background}

Processes associated with modernity, as well as the later (nineteenth century) rise of historicism and related developments of industrial capitalism, western Marxism, and the social sciences, contributed to the privileging of time over space. According to Michel Foucault (1986, 1), "the great obsession of the nineteenth century was history: with its themes of development and of suspension, of crisis, and cycle, themes of the ever-accumulating past, with its great preponderance of dead men and the menacing glaciation of the world." By the last decades of the nineteenth century, the spatial was (re)conceived as being fixed, immobile-a closed system. Space, as Foucault $(1980,70)$ writes, "was treated as the dead, the fixed, the undialectical, the immobile. Time on the contrary was richness, fecundity, life, dialectic." Thus, space became subordinate to time in critical social thought.

Hence, up until the early twentieth century, within the field of comparative education (like most social sciences), time largely took precedence over space. Although early reformers who visited other educational systems since the seventeenth century, but especially in the nineteenth and early twentieth centuries, were traveling to other settings and spaces, they thought that their journeys allowed them to experience educational systems at different stages of development. In this way, they felt they were "time travellers" (Sobe and Fischer 2009).

Many comparativists in the first half of the twentieth century were historians and emphasized the importance of evolutionary time in their work. Isaac Kandel (1933) and Nicholas Hans (1959), for example, can be located within the "forces and factors" tradition of comparative education in their writing about how past events and antecedent factors and forces influenced educational forms, policies, and practices, and "determined" the evolutionary development of educational systems. ${ }^{2}$ Even into the second half of the twentieth century, time has remained an important concept in research in the field. Other historical accounts published in the 1960s and 1970s, for instance, also reflected an emphasis on evolutionary notions of time (e.g., Kazamias 1966).

However, despite this emphasis on time (in our history), it can also be argued that space has always been a central concern in comparative and international education, defining and legitimizing our field. The very nature of our field suggests a focus on spatial units of analysis. Most comparativists

\footnotetext{
${ }^{2}$ Not all early comparativists viewed time this way. Schneider (1961), for example, rejected the national case studies favored by Kandel and Hans, emphasizing instead the notion of "historical immanence," a kind of ideational and institutional cumulative tendency possessed by societies, and the "transnational," anticipating, in some ways, later work by globalization theorists.
} 
focus their attention on geographic entities as units of analyses, comparing educational phenomena across and within different places, including countries, regions, or cities. ${ }^{3}$ This reveals the emphasis on geographic entities (places) in comparative analysis with most, although not all, of the focus still being on the nation-state. ${ }^{4}$

Such studies have largely assumed that countries are homogeneous, equivalent units of analysis and that the nation-state is the container of society. Thus, comparing societies necessarily entails comparing nation-states (Dale and Robertson 2009). The term "methodological nationalism" has been coined to underscore the focus within social sciences research on the nationstate. Methodological nationalism operates both about and for the nation state, to the point where the only reality we can statistically describe is the national or, at best, an international one (Dale and Robertson 2009).

As a result of these limitations, a number of scholars within the field of comparative and international education have proposed new or modified scales of analysis beyond the country or nation-state (e.g., Cowen 2009). For example, Mark Bray and R. Murray Thomas (1995) created a cube to classify comparative and international education studies by level and type. The geographic/locational dimension of the cube includes world regions/continents, countries, states/provinces, districts, schools, classrooms, and individuals. We have, therefore, a number of edited volumes in our field that deal with education in specific geographical regions such as Africa, Latin America, the Middle East, and Nordic countries (e.g., Gvirtz and Beech 2008; O'Dowd 2011; Donn and Manthri 2013). Most of these, however, are still divided into chapters on specific countries within these regions, demonstrating the emphasis once more on the nation-state. Other groupings, related in some cases by geographical contiguity, include economic and political regional organizations (e.g., Asia-Pacific Economic Cooperation, Mercado Común del Sur, North American Free Trade Agreement, the European Union, and Caribbean Community and Common Market), cultural and political links such as the Commonwealth or the notion of "Iberoamerica" (including Portugal, Spain, and all the American countries colonized by Iberian empires), as well as the concept of "civilizations" (Thanh Khoi 2001).

However, while we agree that it is important to expand our spatial units of analysis to include geographic entities previously downplayed in comparative studies, this does not necessarily provoke us to engage in the kind of spatial theorizing that we propose in this article. In other words, while we may develop new spatial units of analysis or scales of analysis beyond the nation-state, this is still an approach that views space as an object of study, rather than a framework for analysis. Before reviewing some key ideas as-

\footnotetext{
${ }^{3}$ Some within our field have conducted temporal comparisons (see Sweeting 2007), but the majority of the work has involved comparisons across space (i.e., geographic entities).

${ }^{4}$ See, e.g., Kandel (1933); Hans (1949); Green (1993); McGinn (1997); O’Dowd (2011).
} 
sociated with the spatial turn, we turn our attention to a binary framework between space and place that many social scientists, including comparative and international education researchers, have deployed and which has hindered the kind of broader thinking about space that we propose here.

\section{The Construction of Binary Distinctions between Space and Place}

This section examines a major metanarrative in the social sciences that has contributed to the construction of binary distinctions between the concepts of space and place. We argue that this dominant account is based on a linear and evolutionary notion of time in which concepts of space and place, what they mean for individuals and social groups, and the relationship between them have "evolved" from premodern isolated populations to the current hyperconnected globalized world. We start by describing this metanarrative and the evolution on which it is based in order to, later, offer a critique and a discussion of the empirical and theoretical limitations that the construction of this binary has produced in the social sciences.

According to prevailing accounts, modernity brought about a rupturing of space from place (and from time, as noted above). In premodern times, place assumed a definite, bounded social meaning. Social relations were by and large circumscribed to a community inside given territorial boundaries. External space was weakly grasped and was normally understood as a mysterious place dominated by external authorities or mythological figures. Thus, in premodern societies, space generally coincided with place (Harvey 1989). The intensity and interconnections of global flows were considered low compared to more local interconnections in premodern times (Held and McGrew 1999).

A number of shifts occurred with modernity-most importantly, the dislocation of space from place. Anthony Giddens (1990) is one of the key theorists to write about the impact of modernity on space-place relations: "The advent of modernity increasingly tears space away from place by fostering relations amongst 'absent' others. . . . In conditions of modernity . . . locales are thoroughly penetrated by and shaped in terms of social influences quite distant from them" (18-19). Following this line of thought, it has been argued that more recent processes of globalization have further contributed to new space-place configurations. While modernity brought about the separation of space from place, there are "hyper" globalists who view globalization as the erasure of place. According to these accounts, globalization means the end or demise of the nation-state (or other local places). This is either celebrated by neoliberals such as Kenichi Omhae (1995) or decried by post-Marxists such as Michael Hardt and Antonio Negri (2000). From these perspectives, as institutions of global governance such as the International Monetary Fund (IMF), General Agreement on Tariffs and Trade (GATT), and the world market take on bigger roles, the sovereignty and 
autonomy of the nation-state is further eroded. The result of economic globalization is the construction of new forms of social organization that will replace the nation-state as the primary economic and political unit of world society (Held and McGrew 1999). Place, according to this dominant metanarrative, is thereby eliminated or at least attenuated, and space rules supreme. As will be discussed, these types of spatial perspectives render "globalization" as a grand narrative of domination (by space) and resistance (of places).

This dominant account of the shift in place-space (or inside-outside) relations, from premodern to contemporary times, works from a number of assumptions about space and place. Place, according to this particular understanding, has territorial contiguity and refers to a physical setting of social activity that is situated geographically (Giddens 1990; Castells 2000b). Places have names and figure on maps. Following this line of thought, place signifies experience, meaning, and belonging (Tuan 1977; Creswell 2004). Place, as an object, has generally come to be associated with the "local" (i.e., our homes, community, city or town, region): that which is lived, everyday and meaningful. It is the familiar setting we go to where we feel safe and secure. In this way, place is the center of our memory and experience: that which is authentic, real, and the lived (Tuan 1974, 1977; Dirlik 2001).

Space, on the other hand, is not confined by territorial contiguity (Castells $2000 \mathrm{~b})$. There are no geographical borders with space; it is always somewhere out there, beyond place. It has come to be associated with something more abstract and ubiquitous-without boundaries. We speak of outer space, not inner space. Space is also considered forward-looking and futuristic. As YiFu Tuan $(1974,8)$ writes, "The future is out there in open space." Space is also equated with movement, flow, and activity - the opposite of place, which is fixed, stable, and secure. Space, moreover, is seen as being "more generic, more amorphous and porous, hard to pin down" than place (Gulson and Symes 2007, 2).

There are a number of problems with this widely accepted account of place and space from premodern to modern and globalized times. For example, this dominant metanarrative assumes that place and space were conjoined in premodern times. However, much research has since demonstrated that this was not the case and that the premodern world was very much characterized by interconnections, links and flows between local communities and those beyond. Eric R. Wolf (1982) in his book Europe and the People without History asserts that everywhere in precontact (with the European) world, "populations existed in interconnections" and "if there were any isolated societies these were but temporary phenomena" (71). A number of the articles in Claire Smith and Graeme K. Ward's (2000) edited collection Indigenous Cultures in an Interconnected World attest to the contact and connections that many indigenous groups of people had with outside "others" in pre- 
modern times. This challenges not only notions of "precontact" pristine societies being unsullied by outside (i.e., Western) influences, but that place was untouched by space-the outside world.

Furthermore, the binary makes assumptions about place that are simply untrue. Place for many is not where fixity, stability, and security are always found. There is nothing inherently stable and secure about place itself. There are some places-prisons, a home where there is domestic abuse, or a refugee camp - that are characterized by tremendous fear, insecurity, and instability. The same can be said of schools. Residential schools in Canada up until the mid-twentieth century were certainly not places of security and comfort for the tens of thousands of First Nations children who were forced to attend them (Miller 1997).

Despite these limitations, many globalization theorists continue to draw upon this binary logic to describe contemporary changing space-place relations. Place continues to be implicitly conceptualized as the local (or the subnational or national), the real, and the stable; and space as the global, something more abstract, futuristic, and beyond us (Harvey 1989; Held and McGrew 1999; Waters 2001). While globalization may have provided the conditions for the stretching out or even the annihilation of place, this thinking begins with the assumption that space and place are ontologically different and historically separated. Place as local and space as global constitute "master categories" that have dominated much of the research on the impact of globalization on local communities and places. As Antonio Escobar (2001, 155-56) explains, "the global is associated with space, capital, history and agency while the local, conversely, is linked to place, labor, and tradition-as well as with women, minorities, the poor and, one might add, local cultures."

Therefore, much globalization research has focused on how hegemonic globalizing processes have affected national educational policies, or how the national has mediated the global. In either case, the emphasis is on the global and the national (or the local) with the latter conceptualized implicitly as a "place" influenced by outside forces. We see this in the work of world culture theorists in our field who posit that the institutions of the nationstate (e.g., education) are shaped at an international level by dominant Western norms and values. World culture theorists maintain a sense of "global inevitability" about these alleged homogenizing processes, which they analyze across a great number of countries and based on categories set at a high level of generality (e.g., Meyer et al. 1992; Baker and LeTendre 2005).

Others have focused on the negative impact of economic (neoliberal) globalization on local places. In such a way, places are assumed to have been untouched and pure prior to contact with the outside. David Harvey, for example, suggests that places are threatened by global flows of capital and people (among other things). The tension between mobile capital and fixed 
places generates a competition between places to attract this capital and can also be the source of crisis: "Old places . . . have to be devalued, destroyed, and redeveloped while new places are created. The cathedral city becomes a heritage center, the mining community becomes a ghost town, the old industrial center is deindustralised, speculative boom towns or gentrified neighbourhoods arise on the frontier of capitalist development or out of the ashes of deindustralised communities" (Harvey 1996, 296). Thus, Harvey emphasizes how local places are influenced in negative ways by globalization. Similarly, there are educational researchers (especially those from a neoMarxist, critical tradition) who have also critiqued neoliberal globalizing processes, highlighting the damaging consequences of globalization, particularly in its economic forms, on educational practices and processes in the global South (e.g., Carnoy and Torres 1994; Altbach 2004), higher education (Giroux 2002; Torres and Schugurensky 2002), and compulsory schooling (e.g., Apple 2010; Litz 2011).

Both world culture theorists and their critics emphasize the nation-state as the main spatial basis of comparison, and even though such authors may not explicitly acknowledge this, they appear to conceptualize global processes as being "out there" influencing local places that receive, modify, or resist these influences. This type of reasoning is an example of oversimple binary views of the relation between space and place and the global and the local. Furthermore, what unites many globalization theorists, including world culture researchers and critics of globalization, is a conception of place as a fixed, stable object of study influenced by globalizing forces. Theorists associated with the "spatial turn" challenged these very ideas, as do we, and it is to this topic that we now turn.

\section{The Spatial Turn}

Michel Foucault (1980) and Henri Lefebvre (1976, 1991) inspired the epistemological and ontological rethinking of the relations between space and time. They rejected the privileging of time over space and suggested that the organization of space was central to the structure and function of globalized capitalism. Space, according to Lefebvre, needs to be understood not only as a concrete, material object, but also as an ideological, socially constructed, and subjective one. Since then, increasing numbers of scholars in the social sciences and humanities have shifted their attention to space as an interpretive framework for understanding social phenomena. Space has entered into a variety of fields of study including economics; anthropology and archaeology; sociology and psychology; political science and, specifically, international relations; history, including art history; and literary, film, cultural, and religious studies. This shift has been characterized as the "spatial turn" (Soja 1989; Warf and Arias 2009). What unites scholars within these fields is a keen sense that space matters and that spatial thinking is now 
essential to the production of knowledge in the social sciences. Contemporary culture, as Frederic Jameson $(1984,89)$ writes, is "increasingly dominated by space and spatial logic."

The spatial turn includes a rethinking of the concepts time, space, and place, and the relationship between them. While there are numerous social theorists engaged in new spatial thinking, we draw primarily upon the work of Manuel Castells (2000a, 2000b, 2011), Henri Lefebvre (1976, 1991), Doreen Massey (1993, 2005, 2009), and Edward Soja (1989, 1996). Here we review some of the key ideas associated with the spatial turn, an orientation that rejects the binaries between place (the local) and space (the global) as outlined above, and emphasize the need for more complex theorizations of space, especially in discussions about the impact of globalization. We start here by describing what is known as a relational notion of space and then comment on the productive functions of space. We will later discuss how these ideas have been and can further be used in research in comparative and international education.

\section{Relational Notion of Space}

A relational notion of space implies understanding that space not only exists in substantial, concrete, and separate forms, but as sets of relations between individuals and groups. Foucault (1986), in his discussion of heterotopias, suggests that heterogeneous and relational spaces characterize the modern world. He writes that space in the modern era takes the form of relations, which he describes as series, trees, or grids, among sites such as the church, theater, museum, fairground, and prison. These are, as Lefebvre (1991) explains, lived spaces, simultaneously concrete and abstract.

The metaphor of the network society (Castells 2000a, 2000b) is based on an interpretation of space as a set of relations that transcend the territorial location of the nodes that constitute a given network. The net as a spatial metaphor questions simplistic views of the shrinking of the world that assume that all locations are increasingly interconnected. At the same time that networks connect and draw people and institutions together, others are pushed farther apart (Murdoch, quoted in Warf 2009). Thus, through a relational notion of space, it is possible to perceive the complexity involved in the processes of time-space compression and understand that even though distance may not be directly related to geographical location, it is still an important concept in researching social and educational phenomena across space. In other words, the ways in which individuals and groups are placed within the compression of time-space are complicated and varied (Massey 2005).

A relational conception of space also contributes to a better understanding of global and local relations. This spatial perspective implies accepting that the global is implicated in the local, and the local in the global. There 
are, as Massey (2009) reminds us, hardly any places that in some way are not party to the making of the global. The global is not just some space, out there, without material basis. It is produced in local settings. Whatever was previously considered "out there" in space, beyond us is someone else's situated and real place. For example, as Thomas Popkewitz (2000) has shown in his analysis of "indigenous foreigners" (4), the work of global heroes such as John Dewey, Paulo Freire, or Lev Vygotsky, and global discourses such as the notion of professionalization "appear to have no apparent 'origin', but are not global or universal. They emerge from particular national or local interest but become part of the authorized discourses of world systems of reason about social and educational reform" (13). As these discourses are taken up in global networks, they are abstracted from the historical experiences in the local context of which they were constructed, and they become floating signifiers that are then relocalized and resignified as they enter specific places and different contexts of power relations (Beech 2009).

A similar argument can be made with respect to how local places "respond" to globalizing forces. There is a tendency to see local places as victims or heroic resistors of external global forces. However, "geographies of resistance" (Pile and Keith 1997) are both global and local. For example, Castells (2011) shows that the "improperly labeled 'anti-globalization movement' $\mathrm{Al}$ Qaeda, and environmental movements might be locally rooted but they also depend on global networks to 'resist' allegedly global forces" (27). Thus, relations of domination and resistance are deployed in contexts that are simultaneously local and global. Global forces are being created in sites such as cities and towns in complex, dynamic, and sometimes incoherent relations (Sassen 2007).

\section{Productive Functions of Space}

Critical spatial theorists also note the need to view both place and space as always in the process of becoming. In his 1991 book The Production of Space, Lefebvre argued that space is socially produced through three interrelated processes of spatialization. These dimensions are spatial practices, representations of space, and spaces of representation. Spatial practice (the material or perceived space) is space as it is interpreted or perceived and referred to as commonsense, and through which we can identify flows and movements in our everyday lives. Representations of space (conceptualized or conceived space) refers to more abstract notions of space as used in the media, maps, town planning, and so on, which operate in ways to represent and make sense of space. And finally, spaces of representation (or lived space) refers to the ways that space is lived, felt, and experienced. This is, as Lefebvre (1991, 39) writes, "space as directly lived through associated images and symbols, and hence the space of "inhabitants' and 'users."

Drawing upon the work of Lefebvre, this view of space has been taken 
up by the urban geographer Soja $(1989,1996)$, who stresses the performative aspect of places that are produced by (and at the same time produce) social activity. Places are performed as individuals inhabit them, but we do not perform our everyday practices in a vacuum. "We are surrounded by the material form of places and their contingent meanings. There is nothing natural or immutable about them-they are social products, but they do provide the context for our practices" (Creswell 2004, 38). This idea sees place as open and not essentialized, as performed and defined by practices as much as it structures and produce practices. What does this spatial orientation mean for scholarship in comparative and international education?

\section{New Spatial Thinking and Comparative and International Education Research}

We have noted that space has been a central concern of the field of comparative and international education for many decades. Comparative researchers have studied education across different scales, with most, although not all, of the focus being on the nation-state. Beyond this particular emphasis on space, there have been others in our field who have taken up space not simply as an object of concern, but as a conceptual tool for analysis. ${ }^{5}$ We focus on the work of two individuals, Rolland Paulston and Stephen Carney, to demonstrate the potential of spatial theorizing in our field. We mention only two here, recognizing that there are others we have neglected to include in this, our partial mapping of new spatial thinking in comparative and international education. We begin with the work of Paulston, a geographer by training, who understood the opportunities that spatiality provided for comparative and international education and took these up in his work on social cartography. Twenty years ago, Paulston (with Liebman) invited readers of Comparative Education Review to engage in social cartography, suggesting that "critical cartography as boundary work offer[ed] comparativeeducation possibilities for examining educational problems 'in light of culturally determined needs, objectives and conditions"” (Raivola 1985, quoted in Paulston and Liebman 1994, 223).

Paulston drew upon the work of critical geographers such as Soja to advance his argument (one that we continue to advance) that spatial theorizing provides the field of comparative and international education with new possibilities for our research. In the introduction to his edited book Social Cartography: Mapping Ways of Seeing Social and Educational Change, Paulston wrote that our "spatial imagination" provides us with the ability to resist disciplinary enclosures, cross borders, and enter into critical dialogue with other imaginations (2000, xix).

Paulston is best known for his macro mapping of paradigms and theories in comparative and international education texts that he treated as a coherent

\footnotetext{
${ }^{5}$ See, e.g., Popkewitz (2000); Robertson (2007); Singh et al. (2007); Sobe and Fischer (2009).
} 
intellectual field. Paulston advocated for the use of critical cartography to map the space of comparative and international education research. His maps are intended as open spaces to social dialogue, and he called upon comparativists to question his maps and subject them to validation through the same kind of rigorous, analytic research that he engaged in himself. As a result, a few within the field have taken up Paulston's call to become social cartographers, mapping educational discourses in diverse ways (e.g., Erkilla 2001; Ahmed 2003; Weidman and Jacob 2011). Yet, over the past 20 years, since Paulston's first publication on social cartography, our field has been slow to engage more vigorously with the spatial turn and other approaches that one might broadly define as postpositivist, reflecting our field's continuing commitment to its modern mission (e.g., Epstein and Carroll 2005, 2011).

Carney's (2009) work is a more contemporary example of the use of space as a methodological and theoretical tool. He starts by suggesting that "educational phenomena in one country must . . . be understood in ongoing relation to other such cases" (63) and in this way he addresses directly the need to look more carefully into connections between educational sites. Borrowing from Arjun Appadurai (1996), Carney notes that globalization is characterized by flows that entail contradiction and inconsistencies, since global flows can liberate and empower and, at the same time, bring up new forms of domination. Methodologically, he suggests that our usual static (sometimes binary) frameworks are not effective to analyze objects that are in motion. From this perspective, even the nation-state is seen as being in motion, always becoming and transforming: "The greatest of these apparently stable objects is the nation-state, which is today frequently characterized by floating populations, transnational politics within national borders, and mobile configurations of technology and expertise" (Appadurai, cited in Carney 2009, 64). In order to address this challenge, Carney uses the concept of "policyscape" in an attempt to move "beyond the reliance on nation, educational system, and school" (67), deploying this concept to connect different reform initiatives at different levels of the educational systems in three different countries (Denmark, Nepal, and China). In this way, he problematizes the construction of local as a static preexisting site and, instead, suggests a more relational view of the local (or place) as a set of social and spatial relations in which global, international, and national forces are combined with individual identities in complex and dynamic ways. Thus, Carney's article addresses the need to analyze connections between sites and to avoid static binary definitions of global/local and space/place.

The examples that we have drawn on above demonstrate that there has been some interest within our field in engaging in spatial theorizing. We wonder, however, why more comparativists have not responded to the spatial turn in their research? We turn to two recent volumes that review various 
ways that space has been taken up in educational research and then devote most of our attention to one area of particular concern to comparative and international education researchers: mobilities and movements of educational policies, practices, and people. Drawing on the examples of educational research engaging in spatial theory from Tara Fenwick, Richard Edwards and Peter Sawchuk's (2011) chapter "Spatial Theory in Educational Research" and Kalervo Gulson and Colin Syme's (2007) edited book Spatial Theories of Education: Policy and Geography Matters, we can map out three general topics that could stimulate the interest of comparativists to foreground space as a tool and framework for educational analysis. These include research on learning spaces and pedagogy, identities in educational spaces, and educational policy research.

One of the most significant applications of spatial theory in educational research has been in relation to learning spaces, the curriculum, and critical pedagogy (Gulson and Symes 2007; Fenwick et al. 2011). Some of this research has included seeing the inside (classroom, school) and outside (home, community) spaces of education as relational sets of practices and mobilities, and the study of institutions as spaces of flux and flows rather than bounded and clearly demarked spaces. A more expansive notion of curriculum and pedagogy as assemblages of the human and nonhuman in their enactments is emphasized in this research (e.g., Mannion 2003, Paechter 2004). Jan Nespor's (1994) "Knowledge in Motion" study of teaching, learning, and curriculum in undergraduate studies in physics and management described the ways that students are organized in space and time and the implications of this for subjectivity and knowledge construction. And literary researchers such as Kevin Leander and Margaret Sheehy (2004) have demonstrated how literacy practices are produced through space-time configurations.

Another topic of interest to educational researchers engaged in the spatial turn has been the construction of identities in educational spaces. Michael Singh, Fazal Rizvi, and Mona Shrestha's work on international students and cosmopolitan identities stands out here. In their work, they pay particular attention to how students' perceptions, conceptions, and experiences of the spaces they negotiated contributed to the production of their cosmopolitan sense of belonging (Singh et al. 2007). They, like others, draw on Lefebvre's work on the production of space to show how the international students in their study continually negotiated their spatial practices, representational spaces, and spaces of representations.

Spatial theory has also been taken up by researchers drawing upon the notion of diaspora stance to inform their understandings of the production of identities of diasporic groups. Rather than focusing on the physical presence of a population in one geographical place, the idea of a diaspora stance draws our attention to the ways that members of a diaspora group maintain networks and allegiances across transnational, cultural, and racial and ethnic 
borders; how political, cultural, and linguistic identities and practices are produced in relation to real or imagined homelands; and how barriers of discrimination and exclusion are addressed (Clifford 1994; Brubaker 2005). Rosalie Rolón-Dow's (2010) study of the perspectives of second-generation Puerto Rican mothers, as they discuss their experiences educating their children, demonstrates how diaspora stances (identities) are produced by the women as they foster Puerto Rican cultural practices and identities with their children and as they negotiate the schooling experiences of their children. She shows how diasporization and racialization processes extend across generations and geography to affect the education of Puerto Rican children.

The last example we turn to is educational policy research. This perhaps is the most obvious area to engage with spatial theorizing given the spatial dimension of globalization. Susan Robertson stands out for her focus on critical socio-spatial theorizing in her analyses of globalization and educational policies. In her 2011 chapter "Spatializing the Sociology of Education," she uses the idea of scale to analyze decentralization and marketization policies, arguing that "scale enables us to trace movements in multiple directions, as new nodes of power and rule are constructed or invigorated, struggled over and legitimated" (Robertson 2011, 24). In her research about publicprivate partnerships in the EU, she demonstrates how the production of space is a highly political process and the outcome of particular projects and struggles. Robertson (2007) argues that the process of creating a European education space is one of territorialization at the European scale. The ideas of territorialization, deterritorialization, and reterritorialization point us toward the significance of concepts such as mobilities and movements in framing our theoretical understandings of spatial relations. It is to this topic that we now turn in our last section as pointing a way forward for future comparativists to foreground the spatial in their research.

\section{Mobilities, Movement, Networks, and Flows: Social Network Analysis}

What unites many of the researchers noted above who are engaging with the spatial turn in meaningful and complex ways is an interest in concepts of mobilities, movement, networks, flow, and flux. Carney (2009) and Singh et al. (2007) do this, as they turn to the work of Appadurai (1996) and his notion of scapes. And the spatial theorizing about curriculum and pedagogy that we reviewed above, along with the notion of diaspora as a stance or project relate to Castells's (2000a, 2000b) ideas of networks and space of flows. This focus on networks and mobilities shifts our thinking away from the notion of space as a container, to conceptualizing the movements, flows, and networks that are constituted across territorial entities.

This focus distinguishes research that addresses space as an object of study (e.g., the space of the classroom) to space as a theoretical tool for analysis. Mobilities theorizing (e.g., Urry 2007) has focused on space as ma- 
terial orderings and disordering, as enactments and performances. As Fenwick et al. (2011) explain: "A focus on mobilities points us towards a tracing of the movements, relations and networks of objects, information and images, and the ways in which flux is regulated, made possible and constrained. Rather than starting analysis from a space out of which objects move, this approach aims to map mobilities, the ways in which spaces are moored, bounded and stabilized for the moment, and the specific (im)mobilities associated with such moorings" (11-12). We propose here the use of a methodological approach, social network analysis (SNA), that focuses on mobilities and movement to demonstrate how spaces are enacted in relation to one another. SNA is a methodological development in the social sciences that draws upon the notion of networks. SNA views social relationships in terms of network theory, comprising nodes (representing individual actors within the network) and ties (which represent relationships between the individuals, such as friendship, kinship, and organizational position; Pinheiro 2011).

In SNA, the focus is on both the identification of the actors in the networks and how they are related to one another. Hence, we are conceptualizing SNA as an analytic method for studying educational phenomena that enables the breaking down of the binary between space and place. SNA is an approach that is situated within the shifts in the social sciences that we outlined above in terms of rethinking relations between space and place by focusing on flows and mobilities. In other words, as Stephen J. Ball (2012, 5) asserts, the focus has shifted to the "spatializing of social relations, on travel and other forms of movement and other transnational interactions and forms of sociality."

The study of networks, connections, and flows is not new in comparative and international education. Authors such as Gita Steiner-Khamsi and Hubert Quist (2000) and Julia Resnik (2008) have included in their analysis of educational transfer a description of the actors involved in the specific cases that they researched and the ways in which they relate to each other. Indeed, the call to engage with SNA in comparative and international education has been previously made by Steiner-Khamsi (2004), who notes that "research on educational transfer lags behind network analysis" and that even though the importance of networks for disseminating educational reform has been highlighted, "we have not provided concrete empirical evidence" (214).

One exception to the lack of empirical use of SNA to analyze educational transfer is the work of Eugenia Roldán and Thomas Schupp (2005, 2006), in which they use this methodological approach, in combination with other approaches, to study the dissemination of the monitorial system of education (also known as the Lancasterian system of education) in early nineteenthcentury Hispanic America. Roldán and Schupp note that the concept of "social networks" has been widely used in the social sciences as a metaphor. Instead, they argue for an analytical use of the concept of networks: "By 
focusing on the dynamics of processes of flow and circulation of people, ideas, objects, merchandise and capital across regions and continents, social network analysis may help to further illuminate the very communication processes that constitute that knowledge transmission: the channels through which information, people, and objects flow, and the ways in which such channels shape-or construct—whatever is being conveyed" $(2005,58)$.

Thus, through the use of SNA it is possible to place the communicative process in the center of inquiry, as the main unit of analysis. Such a relational approach can contribute to the development of more sophisticated interpretations of processes of circulation of educational discourse by looking at how certain factors such as the role of individuals, historical appeals and needs are articulated in complex networks that connect global spaces with local places, and vice versa (Roldán and Schupp 2005).

In this way, Roldan and Shupp (2005) analyze the role of individuals and associations in terms of "connectivity and position" (65), and they emphasize the impressive role that James Thompson had as the most connected node of the network through which the monitorial system was introduced in different American countries. They use the concept of "preferential attachment" (77) to (partly) explain why Thompson was such an attractive node. This concept refers to the rule that the more connected a node is, the more nodes it attracts, and in this way its centrality grows more rapidly than that of other nodes. Also, the earlier a node enters the network, it tends to develop more connections, and Thompson was one of the early adopters of the method. This historical analysis evokes the possibility of applying SNA to explore the role of current policy entrepreneurs in promoting particular educational values and visions globally.

For example, SNA could be used to map the role of Sir Michael Barber, who is considered a leading world authority on education systems and education reform, in terms of his connectivity and position within global educational-business networks. According to the Pearson Inc. website, following his position as a professor at the Institute of Education, University of London, Barber served the UK government as head of the prime minister's delivery unit (from 2001 to 2005) and as chief adviser to the secretary of state for education on school standards (from 1997 to 2001). He moved on to become partner and head of the global education practice at McKinsey and is now the chief education advisor to Pearson PLC Publishing. Barber has advised governments around the world, has worked for the Organization for Economic Cooperation and Development (OECD), World Bank, IMF, and the Department for International Development of the United Kingdom. As Pearson's chief education advisor, he chairs the Pearson Affordable Learning Fund, has published Oceans of Innovation about the rise of Pacific Asia and the implications for global leadership and education, and launched The Learning Curve, an initiative to review, research, and interview innovators worldwide 
about how best to achieve better learning outcomes (see http://www .pearson.com/michael-barber.html).

The spread of education policy ideas through individuals such as Sir Michael Barber are explored by Ball $(2007,2012)$ in his research about the policy activities of edu-business, transnational advocacy networks, and policy entrepreneurs. Ball focuses on the mobility of policies, rather than the simple transfer of educational policies, and suggests that they move through, and are adapted by, networks of social relations involving diverse participants. Ball draws on SNA but considers the method he deploys as "network ethnography" involving "a mapping of the form and content of policy relations in a particular field” $(2012,5)$. Ball's argument is that policy networks constitute new forms of governance and bring into the policy process new sources of authority. The links between international institutions such as the World Bank, OECD, policy entrepreneurs, and for-profit global educational corporations that have been explored by Ball are a potentially interesting educational network that could be further analyzed by comparative education researchers using SNA.

Moreover, mapping and understanding connections and networks in global educational space is also important for the study of transfer in education because networks are not just media to transmit knowledge, but they also contribute to the shaping of that knowledge, in this way drawing our attention to the productive capacity of space. It is in the process of circulation that ideas are constructed, changed, and shaped. Thus, we should avoid a simplistic and static view of transfer as if ideas are produced in one place and then received in another place. Centering our attention in the communicative process can help us grasp the relational dimension of processes of knowledge construction across sites or places (Zimmermann 2009; Roldán 2011) and help us understand place-space relations in more sophisticated and complex ways.

What then does this mean for the comparative study of education in globalized times? SNA could be used to map the networks that constitute educational spaces, and an even more thorough understanding of existing global educational networks such as private-public partnerships, as noted above, or the spread and influence of international standardized assessments. If we take a relational notion of space as a starting point, the best way to model and graphically represent spatial information is not a map of territories, but rather the cartography of connections between individuals and institutions. In many ways this, then, reminds us of Paulston's social cartography project with its emphasis on mapping connections, networks, and relationships. The territorial location of these nodes might be an important aspect to consider, since it might affect the ways in which they relate to each other, but clearly not the only one. In that sense, SNA seems to be a very promising methodological tool to understand empirically and theoretically 
educational spaces, the relations between them, and their productive capacities.

These related notions of flows, networks, connections, and the circulation of discourses, policies, and practices, which have been taken up by spatial theorists, can serve as units of analysis for comparative and international education research to enhance our understanding of local/global interconnectedness. They provide a means to confront limitations outlined earlier in the article about static, binary conceptualizations of place and space. In many respects, the study of connections and circulation has always been at the center of comparative and international education. Educational systems around the globe have been developed through the circulation of discourses, institutions, and practices that have led to strong similarities and convergences in educational systems in different parts of the world (Meyer et al. 1992; Baker and LeTendre 2005). These flows and their consequences have been analyzed in comparative and international education through studies of policy borrowing. However, although there are a few exceptions, most of these studies are based on geopolitical and territorial definitions of space and on static interpretations of transfer, missing the point that it in the process of circulation that knowledge is constructed.

However, for all its appeal, SNA as an analytic device is not a panacea, and, as much as it has the strengths mentioned above, it poses some challenges and has some weaknesses. ${ }^{6}$ One weakness is that the use of this methodological tool is the difficulty in mapping or representing empirically structured relationships of power (Ball 2012). Moreover, the drawing of boundaries of the networks that are being analyzed is difficult, since "processes of diffusion do not stop at any clear border" (Roldan and Shupp 2006, 414). A related methodological challenge concerns the problem arising from the instability and short-term existence of some networks and network relations. Ball (2012) asks, "How do we capture changes in participation, capabilities and asymmetries over time?" and concludes that this is both an "analytical and representational problem" (8).

Despite these limitations, we contend that SNA (or some variant of SNA such as policy network analysis), with its focus on flows and mobilities and the connections between individuals and groups across disparate regions, is an alternative to binary thinking about space and place. We suggest, then, that there is value for comparative and international education researchers to engage more specifically with the mapping of the global field of education, in both its contemporary and historical manifestations. How do individuals connected across regional boundaries, such as diasporic communities, negotiate their educational identities? Who are the actors and institutions that

\footnotetext{
${ }^{6}$ We acknowledge the point made by one of our reviewers that although SNA may appear to be a way out of the space/place dichotomy metanarrative, it does not appear to be a way out of a modernist centering on the human(istic) subject.
} 
participate in global networks-both official and unofficial? How are they connected? What are the relationships between global and local networks? How can we view the local or even the national as open, fluid systems that include the global within them? And most importantly, how can we understand the ways in which educational processes are constructed in the movement between people, products, and ideas. We need to look more carefully at the connections and circulations, at the in-betweenness through which the global and the local (and the educational) are constructed and relate to each other, and at the productive capacity of such thinking.

\section{Conclusion}

Spatiality, we have argued above, can provide comparative and international education research with a tool for the critical analysis of educational patterns, processes, and phenomena. In this article, we described how space has been central to the comparative study of educational patterns and processes, despite what might seem to be an earlier focus on time in our field. We reviewed how the spatial frameworks that have been deployed in much comparative and international education research have mirrored the dominant metanarrative about space and place that has been taken up in the broader social sciences. This dominant paradigm was then critically challenged, after which we presented some current ideas associated with the spatial turn, drawing upon research in critical geography and other disciplines outside of education. These ideas, we argued, provide us with some fresh thinking about how we might further deepen our understanding of the spatial in comparative research. Specifically, we pointed to research on pedagogy and learning spaces, identities, and education policy before turning our attention to social network analysis as providing a way to address the space/ place puzzle, by focusing on networks, flows, and connections.

Earlier in the article we referred to the emphasis on time in much comparative and international education research. Where does time now fit into spatial theorizing? It appears that the spatial turn has been a drive away from metanarratives of historicism, with its evolutionary and developmental approaches to time. However, we are not suggesting that time simply be replaced by an emphasis on space. Rather, we further challenge the binary between space and time, remembering as Massey $(1993,155)$ writes, that "space is not static (i.e. time-less), nor time spaceless, spatiality and temporality are different from each other but neither can be conceptualized as the absence of the other." In addition to viewing space and place in relational productive terms, we also need to think in terms of space-time as being inseparable from and relational to one other.

Furthermore, it would appear that we are making an argument, as Brock (2013) does in the recent special issue on educational space in Comparative Education, that geography ought to join the list of social sciences (e.g., history 
and sociology) that inform comparative studies of education. In some ways this is true. However, the spatial theorizing that we have reviewed in this article has been taken up not only by cultural geographers but also across a wide range of other disciplines including political science, literary studies, and philosophy. Indeed, the discourse of geography has become much broader than the discipline itself (Gregory 1994), and as Lefebvre (1991) reminds us, space is too important to be left to the geographers.

Places and spaces are constructed out of a particular constellation of social relations that are socially produced and reproduced. Thus, if we accept that the landscape of social and political relations is changing, then comparative and international education needs to change to engage in a serious analysis of concepts of space and place, grasping them in their complexity and relationality. We hope that in presenting these arguments we are contributing to the construction of "another" space or set of spatial possibilities in comparative and international education-one that is alternative, relational, and produced out of the ongoing discussions and debates within the field.

\section{References}

Ahmed, Z. N. 2003. "Mapping Rural Women's Perspectives on Nonformal Education Experiences." In Comparative Education Reader, ed. E. R. Beauchamp. New York: Routledge Falmer.

$\rightarrow$ Altbach, P. 2004. "Globalisation and the University: Myths and Realities in an Unequal World.” Tertiary Education and Management 10 (1): 3-25.

Appadurai, A. 1996. Modernity at Large: Cultural Dimensions of Globalization. Minneapolis: University of Minnesota Press.

Apple, M. 2010. Globalization, Social Justice, and Education. New York: Routledge.

Arnove, R., and C. A. Torres, eds. 2012. Comparative Education: The Dialectic of the Global and the Local. Lanham, MD: Rowman \& Littlefield.

Baker, D. P., and G. K. LeTendre. 2005. National Differences, Global Similarities: World Culture and the Future of Schooling. London: Oxford University Press.

Ball, S. J. 2007. Education plc: Understanding Private Sector Participation in Public Sector Education. London: Routledge.

Ball, S. J. 2012. Global Education Inc.: New Policy Networks and the Neo-Liberal Imaginary. London: Routledge.

$\rightarrow$ Beech, J. 2009. "Policy Spaces, Mobile Discourses, and the Definition of Educated Identities." Comparative Education 45 (August): 347-65.

Beech, J. 2011. Global Panaceas, Local Realities: International Agencies and the Future of Education. Frankfurt: Peter Lang.

Bray, M., and R. M. Thomas. 1995. "Levels of Comparison in Educational Systems: Different Insights from Different Literatures and the Value of Multilevel Analyses." Harvard Educational Review 65 (Fall): 472-91.

$\rightarrow$ Brock, C. 2013. "The Geography of Education and Comparative Education." Comparative Education 49 (3): 275-89. 
$\rightarrow$ Brubaker, R. 2005. “The 'Diaspora' Diaspora.” Ethnic and Racial Studies 28:1-19.

$\rightarrow$ Carney, S. 2009. "Negotiating Policy in an Age of Globalization: Exploring Educational 'Policyscapes' in Denmark, Nepal, and China." Comparative Education Review 53 (February): 63-88.

Carnoy, M., and C. A. Torres. 1994. "Educational Change and Structural Adjustment: A Case Study of Costa Rica." In Austerity, Adjustment and Human Resources, ed. J. Samoff. London: Cassell.

$\rightarrow$ Castells, M. 2000a. "Materials for an Exploratory Theory of the Network Society." British Journal of Sociology 51 (January-March): 5-24.

Castells, M. 2000b. The Rise of the Network Society. 2nd ed. Oxford: Blackwell.

Castells, M. 2011. "A Network Theory of Power." International Journal of Communication 5:773-87.

$\rightarrow$ Clifford, J. 1994. "Diasporas." Cultural Anthropology 9:302-38.

Cowen, R. 2009. "Editorial Introduction: The National, the International and the Global." In International Handbook of Comparative Education, ed. R. Cowen and A. M. Kazamias. Dordrecht: Springer.

Cresswell, T. 2004 Place: A Short Introduction. Oxford: Blackwell.

Dale, R., and S. Robertson. 2009. "Beyond Methodological 'Isms' in Comparative Education in an Era of Globalisation." In International Handbook of Comparative Education, ed. R. Cowen and A. M. Kazamias. Dordrecht: Springer.

Dirlik, A. 2001. "Place-Based Imagination: Globalism and the Politics of Place." In Places And Politics in an Age of Globalization, ed. R. Prazniak and A. Dirlik. Lanham, MD: Rowman \& Littlefield.

Donn, G., and Y. A. Manthri, eds. 2013. Education in the Broader Middle East: Borrowing a Baroque Arsenal. Oxford: Symposium.

Erkilla, K. 2001. Mapping the Entrepreneurial Education Debates in the United States, the United Kingdom and Finland. New York: Garland.

$\rightarrow$ Epstein, E. H., and K. T. Carroll. 2005. "Abusing Ancestors: Historical Functionalism and the Postmodern Deviation in Comparative Education." Comparative Education Review 48 (1): 62-88.

Epstein, E. H., and K. T. Carroll. 2011. "Erasing Ancestry: A Critique of Critiques of the "Postmodern Deviation in Comparative Education." In Beyond the Comparative: Advancing Theory and Its Application to Practice, ed. J. Jacobs and J. Weideman. Pittsburgh: University of Pittsburgh Press.

$\rightarrow$ Escobar, A. 2001. "Culture Sits in Places: Reflections on Globalism and Subaltern Strategies of Localization.” Political Geography 20:139-74.

Fenwick, T., R. Edwards, and P. Sawchuk. 2011. Emerging Approaches to Educational Research: Tracing the Sociomaterial. London: Routledge.

Foucault, M. 1980. "Questions of Geography." In Power/ Knowledge: Selected Interviews and Other Writings, 1972-1977, ed. C. Gordon. New York: Pantheon.

$\rightarrow$ Foucault, M. 1986. "Des Espace Autres (Of Other Spaces)." Diacritics 16 (1): 22 27.

Giddens, A. 1990. The Consequences of Modernity. Cambridge: Polity/Blackwell.

Giroux, H. 2002. "Neoliberalism, Corporate Culture, and the Promise of Higher Education: The University as a Democratic Public Sphere." Harvard Educational Review 72 (4): 425-64.

Gregory, D. 1994. "Social Theory and Human Geography." In Human Geography, 
ed. D. Gregory, R. Martin, and G. Smith. Minneapolis: University of Minnesota Press.

Green, A. 1993. Education and State Formation: The Rise of Educational Systems in England, France, and the United States. New York: St. Martin's.

Gulson, K. N., and C. Symes. 2007. "Knowing One's Place: Educational Theory, Policy and the Spatial Turn." In Spatial Theories of Education: Policy and Geography Matters, ed. K. N. Gulson and C. Symes. New York: Routledge.

Gvirtz, S., and J. Beech. 2008. Going to School in Latin America. Westport, CT: Greenwood.

Hans, N. 1949. Comparative Education: A Study of Educational Factors and Traditions. London: Routledge \& Kegan Paul.

$\rightarrow$ Hans, N. 1959. "The Historical Approach to Comparative Education." International Review of Education 5 (3): 299-309.

Hardt, M., and A. Negri. 2000. Empire. Cambridge, MA: Harvard University Press.

Harvey, D. 1989. The Condition of Postmodernity: An Enquiry into the Origins of Cultural Change. Oxford: Basil Blackwell.

Harvey, D. 1996. Justice, Nature and the Geography of Difference. Oxford: Blackwell.

Held, D., and A. McGrew. 1999. Global Transformations: Politics, Economics and Culture. Stanford, CA: Stanford University Press.

Jameson, F. 1984. "Postmodernism—or the Cultural Logic of Late Capitalism." New Left Review 1 (46): 53-92.

Kandel, I. 1933. Comparative Education. Boston: Houghton-Mifflin.

Kazamias, A. 1966. Education and the Quest for Modernity in Turkey. London: Allen \& Unwin.

Leander, K. M., and M. Sheehy, eds. 2004. Spatializing Literacy Research and Practice. New York: Peter Lang.

$\rightarrow$ Lefebvre, H. 1976. "Reflections on the Politics of Space." Antipodes 8:30-37.

Lefebvre, H. 1991. The Production of Space. Oxford: Blackwell.

$\rightarrow$ Litz, D. 2011. "Globalization and the Changing Face of Educational Leadership: Current Trends and Emerging Dilemmas." International Education Studies 4 (3): $47-61$.

Mannion, G. 2003. "Learning, Participation and Identification through School Grounds Development." In Space, Curriculum and Learning, ed. R. Edwards and R. Usher. Greenwich, CT: Information Age.

Massey, D. 1993. "Politics and Space/Time." In Place and the Politics of Identity. ed. M. Keith and S. Pile. London: Routledge.

Massey, D. 2005. For Space. Los Angeles: Sage.

$\rightarrow$ Massey, D. 2009. "The Possibilities of a Politics of Place beyond Place? A Conversation with Doreen Massey." Scottish Geographical Journal 125 (December): 40120.

$\rightarrow$ McGinn, N. 1997. "The Impact of Globalization on National Educational Systems." Prospects 27 (1): 41-54.

Meyer, J. W., D. Kamens, and A. Benavot. 1992. School Knowledge for the Masses: World Models and National Primary Curricular Categories in the 20th Century. Washington, DC: Falmer.

Miller, J. R. 1997. Shingwauk's Vision: A History of Native Residential Schools. Toronto: University of Toronto Press. 
Nespor, J. 1994. Knowledge in Motion: Space, Time, and Signs in Educational Process. Mahwah, NJ: Lawrence Erlbaum.

O'Dowd, M. 2011. Teaching and Researching Comparative and International Education in the Nordic Countries. Rotterdam: Sense.

Ohmae, K. 1995. The End of the Nation State: The Rise of Regional Economies. New York: Simon \& Schuster.

$\rightarrow$ Paechter, C. 2004. "Metaphors of Space in Educational Theory and Practice." Pedagogy, Culture and Society 12 (3): 449-64.

Paulston, R., ed. 2000. Social Cartography: Mapping Ways of Seeing Social and Educational Change. New York: Garland.

$\rightarrow$ Paulston, R., and M. Liebman. 1994. "An Invitation to Postmodern Social Cartography." Comparative Education Review 38 (2): 215-32.

Pile, S., and M. Keith, eds. 1997. Geographies of Resistance. New York: Routledge.

Pinheiro, C. 2011. Social Network Analysis in Telecommunications. Hoboken, NJ: Wiley.

Popkewitz, T. S. 2000. "Globalization/Regionalization, Knowledge, and the Educational Practices." In Educational Knowledge: Changing Relationships between the State, Civil Society, and the Educational Community, ed. T. S. Popkewitz. Albany, NY: SUNY Press.

$\rightarrow$ Raivola, R. 1985. "What Is Comparison? Methodological and Philosophical Considerations." Comparative Education Review 29:262-74.

$\rightarrow$ Resnik, J. 2008. "Introducing a Neo-Weberian Perspective in the Study of Globalisation and Education: Structural Reforms of the Education Systems in France and Israel after the Second World War." Oxford Review of Education 34 (4): 385402.

Robertson, S. 2007. "Public-Private Partnership, Digital Firms, and the Production of a Neoliberal Education Space at the European Scale." In Spatial Theories of Education: Policy and Geography Matters, ed. K. N. Gulson and C. Symes. New York: Routledge.

Robertson, S. 2011. “'Spatializing' the Sociology of Education: Stand-Points, EntryPoints, Vantage-Points.” In The Routledge International Handbook of Sociology of Education, ed. M. W. Apple, S. J. Ball, and L. A. Gandin. London: Routledge.

Roldán, V. E. 2011. "Internacionalización Pedagógica y Comunicación en Perspectiva Histórica: La Introducción del Método de Enseñanza Mutua en Hispanoamérica Independiente." In Internacionalización: Políticas Educativas y Reflexión Pedagógica en un Medio Global, ed. M. Caruso and H. E. Tenorth. Buenos Aires: Granica.

Roldán, V. E., and T. Schupp. 2005. "Bridges over the Atlantic: A Network Analysis of the Introduction of the Monitorial System of Education in Early-Independent Spanish America." Comparativ—Leipziger Beiträge zur Universalgeschichte und vergleichenden Gesellschaftsforschung 15:58-93.

$\rightarrow$ Roldán V. E., and T. Schupp. 2006. "Network Analysis in Comparative Social Sciences." Comparative Education 42 (August): 405-29.

$\rightarrow$ Rolón-Dow, R. 2010. "Taking a Diasporic Stance: Puerto Rican Mothers Educating Children in a Racially Integrated Neighborhood." Diaspora, Indigenous, and Minority Education 4 (4): 268-84.

Sassen, S. 2007. A Sociology of Globalization. New York: Norton. 
$\rightarrow$ Schneider, F. 1961. "The Immanent Evolution of Education: A Neglected Aspect of Comparative Education." Comparative Education Review 4:136-39.

Singh, M., F. Rizvi, and M. Shrestha. 2007. "Student Mobility and the Spatial Production of Cosmopolitan Identities." In Spatial Theories of Education, ed. K. Gulson and C. Symes. London: Routledge.

Smith, C., and G. Ward. 2000. Indigenous Cultures in an Interconnected World. Vancouver: University of British Columbia Press.

Sobe, N. W., and M. G. Fischer. 2009. "Mobility, Migration and Minorities in Education." In International Handbook of Comparative Education, ed. R. Cowen and A. Kazamias. Dordrecht: Springer.

Soja, E. W. 1989. Postmodern Geographies: The Reassertion of Space in Critical Social Theory. London: Verso.

Soja, E. W. 1996. Thirdspace: Journeys to Lost Angeles and Other Real-and-Imagined Places. Oxford: Blackwell.

Soja, E. W. 2009. "Taking Space Personally." In The Spatial Turn: Interdisciplinary Perspective, ed. B. Warf and S. Arias. London: Routledge.

Steiner-Khamsi, G. 2004. "Conclusion: Blazing a Trail for Policy Theory and Practice.” In The Global Politics of Educational Borrowing and Lending, ed. G. SteinerKhamsi. New York: Teachers College Press.

$\rightarrow$ Steiner-Khamsi, G., and H. Quist. 2000. "The Politics of Educational Borrowing: Reopening the Case of Achimota in British Ghana." Comparative Education Review 44 (August): 272-99.

Sweeting, A. 2007. "Comparing Times." In Comparative Education Research: Approaches and Methods, ed. M. Bray, B. Adamson, and M. Mason. Hong Kong: CERC.

Thanh Khoi, L. 2001. Education et civilisations: Genèse du monde contemporain. Paris: Éditions UNESCO / Bruno Leprince Editeur / Horizons du Monde.

$\rightarrow$ Torres, C. A., and D. Schugurensky. 2002. "The Political Economy of Higher Education in the Era of Neoliberal Globalization: Latin America in Comparative Perspective." Higher Education 43:429-55.

Tuan, Y.-F. 1974. “American Space, Chinese Place.” Harper's Magazine, July 8.

Tuan, Y.-F. 1977. Space and Place: The Perspective of Experience. Minneapolis: University of Minnesota Press.

Urry, J. 2007. Mobilities. Cambridge: Polity.

Warf, B. 2009. "From Surfaces to Networks." In The Spatial Turn: Interdisciplinary Perspective, ed. B. Warf and S. Arias. London: Routledge.

Warf, B., and S. Arias. 2009. "Introduction." In The Spatial Turn: Interdisciplinary Perspective, ed. B. Warf and S. Arias. London: Routledge.

Waters, M. 2001. Globalization. 2nd ed. London: Routledge.

Weidman, J. C., and W. J. Jacob, eds. 2011. Beyond the Comparative: Advancing Theory and Its Application to Practice; a Festschrift in Honor of Rolland G. Paulston. Rotterdam: Sense.

Wolf, E. 1982 Europe and a People without History. Berkeley: University of California Press.

Zimmermann, E. 2009. “Global Intellectual Elites.” In The Palgrave Dictionary of Transnational History, ed. A. Iriye and P. I. Saunier. London: Palgrave/Macmillan. 